Arch Virol (1999) 144: 997-1006

Archives of
Virology
$\substack{\text { OSpringer-Verlag } 1999 \\ \text { Prinet in Austria }}$

\title{
Detection of bovine coronaviruses from adult cows with epizootic diarrhea and their antigenic and biological diversities
}

\author{
Brief Report \\ T. Fukutomi ${ }^{1}$, H. Tsunemitsu ${ }^{2}$, and H. Akashi ${ }^{3}$ \\ ${ }^{1}$ Okayama Prefectural Veterinary Diagnostic Laboratory, Mitsu-cho, Okayama, Japan \\ ${ }^{2}$ Shichinohe Research Unit, National Institute of Animal Health, \\ Shichinohe, Aomori, Japan \\ ${ }^{3}$ National Institute of Animal Health, Kannondai, Tsukuba, Ibaraki, Japan
}

Accepted December 17, 1998

Summary. Bovine coronavirus (BCV) was detected by reverse transcriptasePCR, immune electron microscopy or virus isolation from adult cows at 6 out of 6 outbreaks of epizootic diarrhea in Japan. Six BCVs isolated in feces, intestinal content or tracheal exudate of the cows were analyzed for their antigenic properties by cross virus neutralization $(\mathrm{VN})$ tests. The isolates were divided into two groups, one of which had closely related antigenicity with the reference Mebus and Kakegawa strains of BCV, and another which showed significant differences in $\mathrm{VN}$ antibody titers from the reference strains. Two isolates in the latter group, which were from the enteric and respiratory tracts of the same cows, respectively, were distinguished from each other by ELISA using monoclonal antibodies against the Kakegawa strain. The isolates showed various hemagglutination and receptor destroying enzyme titers against chicken or mouse erythrocytes.

Bovine coronavirus (BCV) belongs to antigenic group 2 of the Coronaviridae, and possesses four major structural proteins, the nucleocapsid protein $\mathrm{N}$, the integral membrane glycoprotein (gp) M, the hemagglutinin-esterase gp HE and the spike gp S [4]. It is known that both $\mathrm{HE}$ and $\mathrm{S}$ gps are involved in hemagglutination (HA) activity. The HE gp is a less potent hemagglutinin than the $\mathrm{S} g \mathrm{p}$, as it only agglutinates erythrocytes from mice and rats and not those from adult chickens. The HE gp also exhibits receptor destroying enzyme (RDE) activity [4].

$\mathrm{BCV}$ is known as a major causative agent of calf diarrhea [3, 4, 10, 15, 24, 25] and winter dysentery of adult cattle $[2,4,8,18,28,30]$. It still remains difficult to isolate the virus on cell cultures. Thus, there have been few papers on the isolation 
and antigenicity of BCV, despite numerous reports on their molecular nature. The purpose of this study was to detect BCV from adult dairy cows at 6 outbreaks of epizootic diarrhea in Japan and to compare the antigenic and biological properties of these BCVs with those of the American and Japanese reference strains of BCV.

Diarrheal feces were obtained from 32 adult dairy cows ( 2 to 9 years of age) in 6 farms at 6 outbreaks of epizootic diarrhea in Okayama Prefecture, Japan, during 1995 and 1997. Small and large intestinal contents, and tracheal exudate were also obtained from a dead adult cow with bloody diarrhea at one of the outbreaks. In each outbreak, diarrhea spread to most of the adult cows at each farm within 1 week. No respiratory symptoms were observed in any cow. A total of 35 field samples were diluted 1:10 in Eagle's minimal essential medium (EMEM), clarified by low-speed centrifugation $(2,500 \times \mathbf{g}$ for $10 \mathrm{~min})$, and used for reverse transcriptase PCR (RT-PCR) (30 samples at 5 outbreaks), immune electron microscopy (IEM) (31 samples at 5 outbreaks), and virus isolation (VI) (20 samples at 6 outbreaks). These feces and intestinal contents were also tested for group A rotavirus by latex agglutination tests (Rotascreen; Microgen Bioproducts Ltd., UK), and for Salmonella spp., Campylobacter spp., Coccidium spp. and Cryptosporidium spp. by using standard techniques. Serum samples were also collected from 21 cows at the 3 farms at the acute and convalescent phases of the disease. These paired sera were tested for antibodies to BCV and bovine viral diarrhea virus by virus neutralization (VN) tests.

The Mebus [13] and Kakegawa [1] strains of BCV were used as the reference strains. A hyperimmune sera against these reference strains and 5 isolates of BCV were prepared with guinea pigs according to the method described by Tsunemitsu et al. [30].

The HRT-18 cells derived from human rectal adenocarcinoma [29] were used for VI, indirect immunofluorescence (IF), VN tests. For VI, $0.1 \mathrm{ml}$ of field samples were inoculated onto the HRT-18 cells grown in roller tubes $(10 \times 100 \mathrm{~mm})$ that had been washed three times with EMEM. After adsorption for $90 \mathrm{~min}$ at $37^{\circ} \mathrm{C}, 0.5 \mathrm{ml}$ of EMEM containing $0.5 \mu \mathrm{g} / \mathrm{ml}$ of trypsin was added in each tube. The inoculated cells were incubated in a roller drum for 7 days at $37^{\circ} \mathrm{C}$, and observed for cytopathic effects (CPE). After three sequential passages, 6 isolates were cloned 3 times by limiting dilution method before use. Confirmation of the isolates as BCV was done by using indirect IF tests [2] and IEM with antiserum to the Kakegawa or Mebus strain of BCV. VN tests were carried out using 96-well micro plates as described previously [31].

Primer pairs for RT-PCR were prepared on the basis of the nucleotide sequence of BCV Mebus strain [11]. The sequences of primers were as follows: forward primer, 5'-ACCACCAGTTCTTGATGTGG-3' (45-26 nucleotides upstream from the $\mathrm{M}$ initiation site); reverse primer, 5'-GGCCTAACATACATCCTTCC-3' (391-409 nucleotides downstream from the $\mathrm{M}$ initiation site). The predicted PCR product was 455 base pairs. RNA was extracted by using a Sepa-Gene RNA extraction kit (Sanko Jyunyaku, Japan) according to the manufacturer's instruction. RT-PCR was performed using the GeneAmp RNA PCR core kit (Perkin-Elmer, USA). One microliter of RNA was mixed with 100 pmol of the reverse primer in 
PCR buffer containing $\mathrm{MgCl}_{2}$, four deoxynucleotides and reverse transcriptase in a total volume of $20 \mu \mathrm{l}$ and incubated at $42^{\circ} \mathrm{C}$ for $15 \mathrm{~min}, 99^{\circ} \mathrm{C}$ for $5 \mathrm{~min}$, then $5{ }^{\circ} \mathrm{C}$ for $5 \mathrm{~min}$. PCR reaction with $100 \mathrm{pmol}$ of the forward primer was carried out in a final volume of $100 \mu \mathrm{l}$ for 35 cycles at $95^{\circ} \mathrm{C}$ for $15 \mathrm{sec}$ and $60{ }^{\circ} \mathrm{C}$ for $30 \mathrm{sec}$. PCR products were resolved by electrophoresis in a $2 \%$ agarose gel and visualized by ethidium bromide staining.

The field samples and isolates were processed and examined by IEM as described previously [18]. These samples were reacted with guinea pig anti-BCV (Mebus or Kakegawa) serum, negatively stained, and examined by using a JEM1010 electron microscope (Jeol Ltd., Japan).

An ELISA using monoclonal antibodies (Mabs) for antigenic analysis of BCV was conducted as described previously [21]. Four Mabs against the Kakegawa strain of BCV (4H4 and 7F5 to the $\mathrm{S}$ gp, and 2C8 and 1D11 to the $\mathrm{N}$ protein [21]) were kindly supplied by Dr. M. Sato, Department of Agriculture, Tochigi Prefectural Office, Tochigi, Japan.

HA tests were carried out with $1 \%$ and $0.5 \%$ suspensions of mouse and chicken erythrocytes, respectively, at $4{ }^{\circ} \mathrm{C}$ and $37^{\circ} \mathrm{C}$ according to the microplate method described by Sato et al. [22]. The BCV strains were partially purified from infected cell culture supernatants by ultracentrifugation through a $30 \%$ sucrose cushion, which were concentrated approximately 50 -fold. The plates incubated at $4{ }^{\circ} \mathrm{C}$ were moved to $37^{\circ} \mathrm{C}$ for $2 \mathrm{~h}$ to measure inactivation of receptors reflected by the disaggregation of the $\mathrm{BCV}$-erythrocyte complexes mediated by the RDE activity [27].

PCR products of $455 \mathrm{bp}$ were detected in 16 of 30 field samples ( 5 of 5 outbreaks of epizootic diarrhea) (Table 1). The small intestinal content produced no PCR product, while the large intestinal content and tracheal exudate obtained from the same cow were positive in the PCR. As shown in Fig. 1, PCR products were detected in 4 of 5 fecal samples of adult cows at the outbreak in August (lanes 1,3-5). Characteristic coronavirus-like particles were detected in 19 of 31 samples (5 of 5 outbreaks of epizootic diarrhea) by IEM (Table 1). The particles were approximately 70 to $130 \mathrm{~nm}$ in diameter and had short and large projections (data not shown). The 4 PCR-positive samples collected in August were also positive in IEM. The agreement of the results between these tests was 93\%. The paired sera from 20 of 21 cows ( 3 of 3 outbreaks of epizootic diarrhea) showed seroconversion (4-fold increase) to $\mathrm{BCV}$, but no seroconversion to bovine viral diarrhea virus was observed. All fecal and intestinal samples were negative for group A rotavirus, Salmonella spp., Campylobacter spp., Coccidium spp. and Cryptosporidium spp.

Six BCV strains designated the 95C6, 95C7, 96C1, 96CT2, 96CE3 and 96C4 strains were isolated in 4 diarrheal feces (95C6, 95C7, 96C1 and 96C4), 1 large intestinal content (96CE3), and 1 tracheal exudate (96CT2) from 5 adult cows at 4 outbreaks of epizootic diarrhea (Table 1). CPE characterized by syncytium formation on HRT-18 cells was observed after two to three serial passages. Cross VN tests were performed with antisera against the 5 isolates and 2 reference strains. The antisera against the reference strains showed 8 to 32 -fold lower VN 
Table 1. Detection of BCV by RT-PCR, immune electron microscopy (IEM) and virus isolation (VI) in diarrheal feces, intestinal contents and a tracheal exudate of adult cows at 6 outbreaks of epizootic diarrhea

\begin{tabular}{lclllc}
\hline Outbreak & No. sample & RT-PCR & IEM & VN & Seroconversion $^{\text {a }}$ \\
\hline $\mathrm{A}^{\mathrm{b}}$ & 6 & $4 / 5^{\mathrm{c}}$ & $4 / 6$ & $0 / 4$ & $\mathrm{NT}^{\mathrm{d}}$ \\
$\mathrm{B}$ & 6 & $2 / 5$ & $4 / 6$ & $1 / 3$ & $\mathrm{NT}$ \\
$\mathrm{C}$ & $13^{\mathrm{e}}$ & $7 / 13$ & $8 / 12$ & $2 / 7$ & $+(5 / 5)^{\mathrm{f}}$ \\
$\mathrm{D}$ & 1 & $1 / 1$ & $1 / 1$ & $1 / 1$ & $\mathrm{NT}$ \\
$\mathrm{E}$ & 6 & $2 / 6$ & $2 / 6$ & $0 / 2$ & $+(6 / 7)$ \\
$\mathrm{F}$ & 3 & $\mathrm{NT}$ & $\mathrm{NT}$ & $2 / 3$ & $+(9 / 9)$ \\
\hline Total & 35 & $16 / 30$ & $19 / 31$ & $6 / 20$ & $(20 / 21)$
\end{tabular}

${ }^{\mathrm{a}}$ Defined as 4-fold or more increase of virus neutralization antibody titers to BCV (Mebus) in convalescent phase sera compared with those in acute phase sera

${ }^{\mathrm{b}}$ Observed in the summer of 1996

${ }^{\mathrm{c}}$ No. positive /No. tested

${ }^{\mathrm{d}}$ Not tested

${ }^{\mathrm{e}}$ Includes samples of large and small intestinal contents and a tracheal exudate from a dead adult cow

${ }^{\mathrm{f}}$ No. of seroconverted cows/No. of tested cows

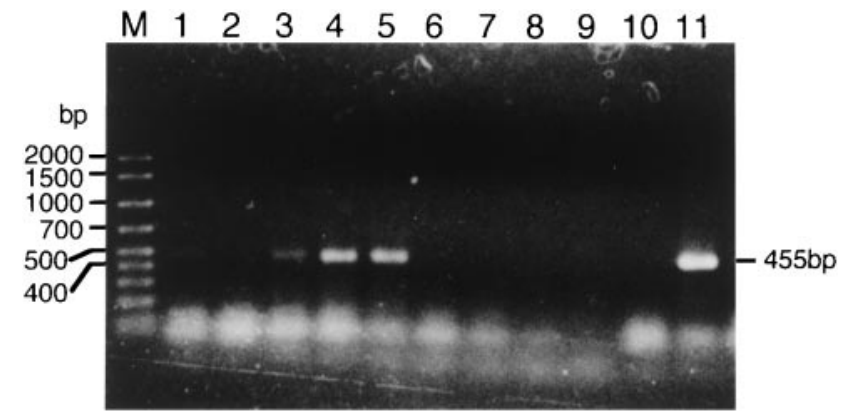

Fig. 1. Agarose gel electrophoresis of the RT-PCR products amplified from fecal specimens obtained from adult cows with epizootic diarrhea in August. $M$ Molecular weight marker (Ampli Size DNA size standard; molecular sizes of the marker are indicated on the left in base pair); 1-5 diarrheal feces; 6-9 normal control feces of cows; 10 uninfected cell supernatant; $11 \mathrm{BCV}$ Kakegawa strain infected cell supernatant. A PCR product of approximately $455 \mathrm{bp}$ was detected in $1,3-5$ and 11

antibody titers to the 96C1, 96CT2, 96CE3 and 96C4 strains than to the homologous strains. The antisera against these 4 isolates also showed 4 to 16 -fold lower $\mathrm{VN}$ antibody titers to the reference strains than to the homologous isolates (Table 2 ). According to the results, the isolates were divided into two groups. The first group (95C6 and 95C7) showed closely related antigenicity with the reference strains of BCV. The rest of the isolates showed significant antigenic differences from the reference strains of $\mathrm{BCV}$.

Although all BCVs reacted in ELISA with 2 Mabs recognizing the $\mathrm{N}$ protein (1D11 and 2C8), various reactivities of the isolates with 2 Mabs recognizing the $S$ 
Table 2. Virus neutralization (VN) tests using antisera against the reference strains (Mebus and Kakegawa) and the isolates of BCV

\begin{tabular}{|c|c|c|c|c|c|c|c|}
\hline \multirow[b]{2}{*}{$\mathrm{BCV}$ strain $^{\mathrm{b}}$} & \multicolumn{7}{|c|}{$\mathrm{VN}$ antibody titers ${ }^{\mathrm{a}}$ of hyperimmune guinea pig sera to } \\
\hline & Mebus & Kakegawa & $95 \mathrm{C6}$ & $96 \mathrm{C} 1$ & $96 \mathrm{CT} 2$ & 96CE3 & $96 \mathrm{C} 4$ \\
\hline Mebus & 2048 & 2048 & 8192 & $\underline{1024}$ & $\underline{512}$ & 2048 & $\underline{512}$ \\
\hline Kakegawa & 1024 & 1024 & 4096 & $\overline{1024}$ & $\overline{512}$ & $\overline{1024}$ & $\overline{512}$ \\
\hline $95 \mathrm{C} 6$ & 1024 & 1024 & 4096 & $\overline{8192}$ & $1 \overline{024}$ & $\overline{2048}$ & $2 \overline{2048}$ \\
\hline $95 \mathrm{C} 7$ & 1024 & 1024 & 4096 & $\overline{4096}$ & 512 & $\overline{2048}$ & 1024 \\
\hline $96 \mathrm{C} 1$ & $\underline{256}$ & $\underline{128}$ & 2048 & $\overline{16384}$ & $2 \overline{048}$ & $\overline{8192}$ & $\overline{4096}$ \\
\hline $96 \mathrm{CT} 2$ & $\underline{64}$ & $\underline{32}$ & 4096 & 16384 & 2048 & 8192 & 4096 \\
\hline $96 \mathrm{CE} 3$ & $\underline{128}$ & $\underline{\overline{64}}$ & 2048 & 16384 & 4096 & 8192 & 4096 \\
\hline $96 \mathrm{C} 4$ & $\underline{256}$ & 64 & 2048 & 32768 & 2048 & 8192 & 4096 \\
\hline
\end{tabular}

${ }^{a}$ Expressed as the reciprocal of the highest dilution of serum inhibiting cytopathic effects. Homologous titers are in bold. Titers which differed by 4 -fold or greater with homologous titers are underlined

${ }^{b}$ The $96 \mathrm{CT} 2$ and 96CE3 strains were isolated from the tracheal exudate and large intestinal content of a dead adult cow, respectively

Table 3. Reactivity of the BCV strains to monoclonal antibodies (Mabs) against the Kakegawa strain by enzyme-linked immunosorbent assay (ELISA)

\begin{tabular}{|c|c|c|c|c|}
\hline \multirow[b]{2}{*}{$\mathrm{BCV}$ strain $^{\mathrm{a}}$} & \multicolumn{4}{|c|}{ ELISA titers of Mabs to } \\
\hline & $4 \mathrm{H} 4^{\mathrm{b}}$ & $7 F 5^{b}$ & $1 \mathrm{D} 11^{\mathrm{c}}$ & $2 \mathrm{C} 8^{\mathrm{c}}$ \\
\hline Mebus & 6400 & 25600 & 400 & 800 \\
\hline Kakegawa & 25600 & 12800 & 1600 & 3200 \\
\hline $95 \mathrm{C} 6$ & $<25$ & 6400 & 1600 & 6400 \\
\hline $95 \mathrm{C} 7$ & $<25$ & 6400 & 800 & 6400 \\
\hline $96 \mathrm{C} 1$ & 400 & 12800 & 200 & 1600 \\
\hline $96 \mathrm{CT} 2$ & $<25$ & $<25$ & 1600 & 6400 \\
\hline 96CE3 & 12800 & 6400 & 1600 & 6400 \\
\hline $96 \mathrm{C} 4$ & $<25$ & $<25$ & 1600 & 3200 \\
\hline
\end{tabular}

${ }^{\mathrm{a}}$ The $96 \mathrm{CT} 2$ and 96CE3 strains were isolated from the tracheal exudate and large intestinal content of a dead adult cow, respectively

${ }^{b}$ Mabs to the spike glycoprotein of the Kakegawa strain

${ }^{\mathrm{c}}$ Mabs to the nucleocapsid protein of the Kakegawa strain 
gp (4H4 and 7F5) were observed. The 96C1 and 96CE3 strains reacted with both anti-S gp Mabs, while the 95C6 and 95C7 strains lacked reactivity to the Mab 4H4, and the 96CT2 and 96C4 strains lacked reactivity to both anti-S gp Mabs. These results clearly show that the isolates were divided into three groups (Table 3). Interestingly, the 95C6 and 95C7 strains were distinguished from the reference strains by the reactivities of the Mab $4 \mathrm{H} 4$, whereas these two isolates revealed similar antigenicity to the reference strains by VN tests using polyclonal antisera. Similarly, although the 96CE3 strain was differentiated from the reference strains by the VN tests, the reactivities of this isolate to the Mabs were similar to those of the reference strains. Surprisingly, the 96CE3 and 96CT2 strains isolated in the large intestinal content and tracheal exudate from the same cow, respectively, had different reactivity patterns against anti-S gp Mabs.

The HA and RDE titers of semipurified BCV strains are summarized in Table 4. All strains agglutinated mouse erythrocytes at $4{ }^{\circ} \mathrm{C}$ with similar HA titers, and no distinct differences except for the $95 \mathrm{C} 6$ and $95 \mathrm{C} 7$ strains were observed in HA titers against mouse erythrocytes at $4^{\circ} \mathrm{C}$ and $37^{\circ} \mathrm{C}$. All strains also agglutinated chicken erythrocytes at $4{ }^{\circ} \mathrm{C}$, but the HA titers varied among the strains. At $37^{\circ} \mathrm{C}$, most of the strains did not agglutinate chicken erythrocytes. RDE activity with chicken erythrocytes was detected in all strains of BCV. RDE activity with mouse erythrocytes was detected only in the 95C6 and 95C7 strains. The differences in HA titers at $4{ }^{\circ} \mathrm{C}$ and $37^{\circ} \mathrm{C}$ showed good agreement with the RDE titers. This suggests that comparison of HA titers at $4{ }^{\circ} \mathrm{C}$ and $37^{\circ} \mathrm{C}$ might provide an alternative method for evaluating RDE activity.

Table 4. Hemagglutination (HA) and receptor destroying enzyme (RDE) activities of semipurified $\mathrm{BCV}$ strains

\begin{tabular}{|c|c|c|c|c|c|c|c|}
\hline \multirow{3}{*}{$\begin{array}{l}\text { BCV } \\
\text { strain }^{b}\end{array}$} & \multirow{3}{*}{$\begin{array}{l}\text { Infectivity } \\
\text { titer }^{c}\end{array}$} & \multicolumn{4}{|c|}{ HA titer } & & \\
\hline & & \multicolumn{2}{|c|}{$4{ }^{\circ} \mathrm{C}$} & \multicolumn{2}{|c|}{$37^{\circ} \mathrm{C}$} & \multicolumn{2}{|c|}{ RDE titer ${ }^{\mathrm{a}}$} \\
\hline & & mouse & chicken & mouse & chicken & mouse & chicken \\
\hline Mebus & 8.00 & 16384 & $>32768$ & 16384 & 8192 & $<2$ & $>4$ \\
\hline Kakegawa & 8.00 & 4096 & 8192 & 8192 & 4096 & $<2$ & 2 \\
\hline $95 \mathrm{C} 6$ & 8.00 & 16384 & 8 & 16 & $<2$ & 2048 & $>4$ \\
\hline $95 \mathrm{C7}$ & 7.75 & 65536 & 8 & 32 & $<2$ & 2048 & $>4$ \\
\hline $96 \mathrm{C} 1$ & 7.75 & 512 & 8 & 2048 & $<2$ & $<2$ & $>4$ \\
\hline 96CT2 & 8.25 & 4096 & 8192 & 8192 & $<2$ & $<2$ & $>4096$ \\
\hline 96CE3 & 8.25 & 16384 & 128 & 32768 & $<2$ & $<2$ & $>64$ \\
\hline $96 \mathrm{C} 4$ & 8.25 & 8192 & 8192 & 8192 & $<2$ & 2 & $>4096$ \\
\hline
\end{tabular}

${ }^{\mathrm{a}}$ Expressed as the reciprocal of the highest dilution of virus causing complete disappearance of HA patterns at $4{ }^{\circ} \mathrm{C}$ after $2 \mathrm{~h}$ incubation at $37^{\circ} \mathrm{C}$

${ }^{\mathrm{b}}$ The 96CT2 and 96CE3 strains were isolated from the tracheal exudate and large intestinal content of a dead adult cow, respectively

${ }^{\mathrm{c}} \log _{10} \mathrm{TCID}_{50} / \mathrm{ml}$ 
Bovine coronavirus is known as a primary pathogen in neonatal calf diarrhea. The virus is also associated with winter dysentery of adult cattle. In Japan, BCV has been reported as the etiological agent in adult cattle with epizootic diarrhea [28] that occurred throughout the entire country. In the present study, we tried to detect $\mathrm{BCV}$ in feces, intestinal contents or tracheal exudate from 33 adult cows at 6 outbreaks of epizootic diarrhea by the RT-PCR, IEM and VI tests. The rate of positive reactions was very high in the RT-PCR (16 of 30 samples at 5 of 5 outbreaks) and IEM (19 of 31 samples at 5 of 5 outbreaks), and the results of these 2 tests showed good agreement. No association with other pathogens was observed in these samples. These results suggest that BCV might be associated with epizootic diarrhea of adult cattle at these outbreaks. Also, the RT-PCR developed in this study may be useful for detecting BCV. Interestingly, BCV was detected by RT-PCR and IEM in 4 of 5 fecal samples from adult cows at the outbreak of epizootic diarrhea in August. Several papers have reported that cold stress, e.g. chilling due to low environmental temperatures including cold drinking water or wide fluctuations in temperatures, is a important risk factor to initiate winter dysentery $[17,32]$. The present study indicated that cold stress might not always be needed to initiate adult cow diarrhea associated with BCV.

The previous reports described that $\mathrm{BCV}$ also has a tissue tropism to the upper respiratory tract in calves and young cattle $[7,12,16,20,26,31]$ and causes respiratory diseases $[4,26]$. However, $\mathrm{BCV}$ has not been detected in the upper respiratory tract in adult cattle although the possibility of respiratory infection of $\mathrm{BCV}$ in adult cattle was pointed out [26]. In this study, BCV (96CT2) was isolated from a tracheal exudate as well as a large intestinal content (96CE3) of a dead adult cow with bloody diarrhea although this cattle did not show clinical signs of respiratory disease. This result suggests that $\mathrm{BCV}$ may have a tissue tropism to the upper respiratory tract in adult cows. Further studies are needed to clarify whether BCV can cause respiratory disease in adult cattle because some cows showing winter dysentery develop nasolacrimal discharge and cough [17].

Both the $\mathrm{S}$ and HE gps cause HA to bind surface receptors containing Neu5, $9 A c 2$ [23]. The HE gp is a less potent hemagglutinin than the $S$ gp, therefore it only agglutinates mouse and rat erythrocytes but not chicken erythrocytes which possess fewer surface receptors [23]. Some BCV-infected cell culture supernatants did not agglutinate chicken erythrocytes at $4{ }^{\circ} \mathrm{C}$ (data not shown), as similar results were reported previously [27]. Thus, the BCV strains were semipurified from infected cell culture supernatants, which were concentrated approximately 50 -fold. All semipurified strains agglutinated chicken erythrocytes at $4{ }^{\circ} \mathrm{C}$, but variations of HA titers were observed among strains. This result suggests that the differences of receptor binding properties of the $\mathrm{S}$ gp exist among BCV strains. High RDE activity against mouse erythrocytes was observed in some strains, which was not observed in the previous reports [27, 30]. These high RDE titers with mouse erythrocytes could be explained by the fact that the RDE activity of these strains is higher than other strains because detection of this activity with mouse erythrocytes is harder than with chicken erythrocytes for these abundant surface receptors. 
Although BCV has been classified as a single serotype $[4,16]$, some reports described antigenic variations among BCV strains $[2,5,6,9,14,30]$. Tsunemitsu and Saif [30] reported that some BCV isolates were antigenically distinguished from the Mebus strain in one-way direction by cross VN tests using polyclonal antisera. In the present study, the reference strains Mebus and Kakegawa were closely related, and the isolates were divided into 2 antigenic groups by cross VN tests: the first group ( 2 strains) was closely related to the antigenicity of the reference strains, and the second group (4 strains) showed significant differences of the antigenicity of the reference strains. These results support the conclusion that BCVs are divided into at least 2 serological subtypes, one is Mebus-like and the others is not [30]. These antigenic variations should be considered for the development of a vaccine against BCV.

The viruses were also divided into several antigenic groups according to the reactivity of the Mabs. The antigenic diversities of BCV with the reactivity of the Mabs and polyclonal antisera exhibited no correlation with each other. The reason for this discrepancy is unknown, but it might be explained that the epitopes recognized by the Mabs were not immunodominant sites, which were not reflected by polyclonal antisera. Interestingly, the 96CE3 and 96CT2 isolated from the enteric and respiratory tracts of the same cow, respectively, belonged to different antigenic groups according to the reactivity of the Mabs. Recently, Storz et al. [26] reported that $\mathrm{BCV}$ isolated from respiratory tracts had different antigenic and biological properties from those of $\mathrm{BCV}$ isolated from enteric tracts, whereas some investigations could not find any difference between enteric and respiratory BCVs $[16,31]$. Our result might indicate that the cow was infected with BCVs having different antigenicity simultaneously. Alternatively, mutation of the virus might occur during infection. Further studies are in progress to compare the nucleotide sequences of the $\mathrm{S}$ and $\mathrm{HE}$ genes of the isolates to determine the domains which cause antigenic diversity.

\section{References}

1. Akashi H, Inaba Y, Miura Y, Tokuhisa S, Satoda K (1980) Properties of a coronavirus isolated from a cow with epizootic diarrhea. Vet Microbiol 5: 265-276

2. Benfield DA, Saif LJ (1990) Cell culture propagation of a coronavirus isolated from cows with winter dysentery. J Clin Microbiol 28: 1454-1 457

3. Bridger JC, Woode GN, Meyling A (1978) Isolation of coronaviruses from neonatal calf diarrhea in Great Britain and Denmark. Vet Microbiol 3: 101-113

4. Clark MA (1993) Bovine coronavirus. Br Vet J 149: 51-70

5. Dea S, Roy RS, Elazhary MA (1982) Antigenic variation among calf diarrhea coronaviruses by immunodiffusion and counterimmuno electrophoresis. Ann Rech Vet 13: 351-356

6. El-Ghorr AA, Snodgrass DR, Scott FM, Campbell I (1989) A serological comparison of bovine coronavirus strains. Arch Virol 104: 241-248

7. Heckert RA, Saif LJ, Myers GW (1989) Development of protein A-gold immunoelectron microscopy for detection of bovine coronavirus in calves: comparison with ELISA and direct immunofluorescence of nasal epithelial cells. Vet Microbiol 19: $217-231$ 
8. Horner GW, Hunter R, Kirkbrid CA (1975) A coronavirus-like agent present in faeces of cows with diarrhea. N Z Vet J 33: 98

9. Hussain KA, Storz J, Kousoulas KG (1991) Comparison of bovine coronavirus (BCV) antigens: monoclonal antibodies to the spike protein distinguish between vaccine and wildtype strains. Virology 183: 442-445

10. Langpap TJ, Bergeland ME, Reed DE (1979) Coronaviral enteritis of young calves: Virologic and pathologic findings in naturally occurring infections. Am J Vet Res 34: $145-150$

11. Lapps W, Hogue BG, Brian DA (1987) Sequence analysis of the bovine coronavirus nucleocapsid and matrix protein genes. Virology 157: 47-57

12. McNulty MS, Bryson DG, Allan GM, Logan EF (1984) Coronavirus infection of the bovine respiratory tract. Vet Microbiol 9: 425-434

13. Mebus CA, Stair EL, Rhodes MB, Twiehaus MF (1973) Neonatal calf diarrhea: propagation, attenuation, and characteristics of coronavirus-like agents. Am J Vet Res 34: $145-150$

14. Michaud L, Dea S (1993) Characterization of monoclonal antibodies to bovine enteric coronavirus and antigenic variability among Quebec isolates. Arch Virol 131: 455-465

15. Morin M, Lamothe P, Gagnon A, Malo R (1974) A case of viral neonatal calf diarrhea in a Quebec dairy herd. Can J Comp Med 38: 236-242

16. Reynolds DJ, Debney TG, Hall GA, Thomas LH, Parsons KR (1985) Studies on the relationship between coronaviruses from the intestinal and respiratory tracts of calves. Arch Virol 85: 71-83

17. Saif LJ (1990) A review of evidence implicating bovine coronavirus in the etiology of winter dysentery in cows: an enigma resolved? Cornell Vet 80: 303-311

18. Saif LJ, Bohl EH, Kohler EM, Hughes JH (1977) Immune electron microscopy of transmissible gastroenteritis virus and rotavirus (reovirus-like agent) of swine. Am J Vet Res 38: $13-20$

19. Saif LJ, Brock KV, Redman DR, Kohler EM (1991) Winter dysentery in dairy herds: electron microscopic and serological evidence for an association with coronavirus infection. Vet Rec 128: 447-449

20. Saif LJ, Redman DR, Moodrhead PD, Theil KW (1986) Experimentally induced coronavirus infections in calves: viral replication in the respiratory and intestinal tracts. Am J Vet Res 47: 1426-1 432

21. Sato M, Akashi H, Hirai S, Kimura Y, Takahashi M (1991) Production of monoclonal antibodies against the Kakegawa strain of bovine coronavirus and their characterization. J Vet Med Sci 53: 147-148

22. Sato K, Inaba Y, Kurogi H, Takahashi E, Satoda K, Omori T, Matsumoto M (1977) Hemagglutination by calf diarrhea coronavirus. Vet Microbiol 2: 83-87

23. Schltze B, Gross HJ, Brossmer R, Herrler G (1991) The S protein of bovine coronavirus is a hemagglutinin recognizing 9-O-acetylated sialic acid as a receptor determinant. J Virol 65: 6 232-6237

24. Sharpee RL, Mebus CA, Bass EP (1976) Characterization of a calf diarrhea coronavirus. Am J Vet Res 37: 1 031-1041

25. Stair EL, Rhodes MB, White RG, Mebus CA (1972) Neonatal calf diarrhea: purification and electron microscopy of a coronavirus-like agent. Am J Vet Res 33: $1147-$ 1156

26. Storz J, Stine L, Liem A, Anderson A (1996) Coronavirus isolation from nasal swab samples in cattle with signs of respiratory tract disease after shipping JAVMA 208: 1452-1455 
27. Storz J, Zhang XM, Rott R (1992) Comparison of hemagglutinating, receptor-destroying, and acetylesterase activities and virulent bovine coronavirus strains. Arch Virol 125: 193-204.

28. Takahashi E, Inaba Y, Sato K, Ito Y, Kurogi H, Akashi H, Satoda K, Omori T (1980) Epizootic diarrhea of adult cattle associated with a coronavirus-like agent. Vet Microbiol 5: $151-154$

29. Tompkins WA, Watrach AM, Schmale JD, Shults RM, Harris JA (1974) Cultural and antigenic properties of newly established cell strains derived from adenocarcinomas of the human colon and rectum. J Natl Cancer Inst 52: 1 101-1 110

30. Tsunemitsu H, Saif LJ (1995) Antigenic and biological comparisons of bovine coronaviruses derived from neonatal calf diarrhea and winter dysentery of adult cattle. Arch Virol 140: 1303-1311

31. Tsunemitsu H, Yonemichi H, Hirai T, Kudo T, Onoe S, Mori K, Shimizu M (1991) Isolation of bovine coronavirus from feces and nasal swabs of calves with diarrhea. J Vet Med Sci 53: 433-437

32. White ME, Schukken YH, Tanksley B (1989) Space-time clustering of, and risk factors for, farmer-diagnosed winter dysentery in dairy cattle. Can Vet J 30: 948-951

Authors' address: Dr. H. Akashi, National Institute of Animal Health, 3-1-1 Kannondai, Tsukuba, Ibaraki 305-0856, Japan.

Received August 31, 1998 